\title{
Isolation and identification of Pyrenophora chaetomioides from winter oat in Hungary
}

\author{
A. Palágyi ${ }^{1} \cdot$ J. Bakonyi ${ }^{2} \cdot$ M. Tar $^{3} \cdot$ M. Cséplö ${ }^{4} \cdot$ M. Csősz ${ }^{1}$
}

Received: 3 October 2019 / Accepted: 30 October 2019 / Published online: 27 February 2020

(c) The Author(s) 2020

\begin{abstract}
The aim of this study was to identify a fungal pathogen that caused necrotic leaf spots in experimental plots of oat in two remote regions of Hungary, the Southern Great Plain and Central Transdanubia. Two monosporic isolates, one from each region, were subjected to morphological and molecular investigations, and their pathogenicity to oat, barley and wheat seedlings was tested by artificial inoculations. Morphology of cultures and conidia matched well the description of genus Drechslera, the asexual stage of Pyrenophora. The natural host and higher pathogenicity of both isolates to oat than to barley and wheat suggested that the fungus represented the primarily oat pathogen P. chaetomioides. Although accurate species identification could not be achieved due to overlapping morphology and host range among the oat and barley pathogenic Pyrenophora spp., PCR amplification and direct sequencing of the ITS1-5.8S-ITS2 region of the nuclear ribosomal DNA revealed $100 \%$ identity amongst our isolates and several reference strains of $P$. chaetomioides, justifying the species identity of the fungus we found on oats. Our study also confirmed an earlier, symptom-based observation about the occurrence of Pyrenophora leaf blotch disease in experimental plots in Hungary, and is the first to prove the presence of its causal agent, $P$. chaetomioides, based on isolation and accurate species identification.
\end{abstract}

Keywords Avena $\cdot$ Fungal disease $\cdot$ Leaf blotch

\section{Introduction}

Several oat species (e.g. Avena abyssinica Hochst., A. byzantina K. Koch, A. nuda L., A. sativa L., A. sterilis L., A. strigosa Schreb.) are cultivated in the world, particularly in the subtropical and temperate zones. Ancestors of the most widely produced oat species (A. sativa) originated from the Fertile Crescent of the Near East, from where they spread

In memoriam M. Csősz.

J. Bakonyi

bakonyi.jozsef@agrar.mta.hu

1 Cereal Research Non-Profit Limited Company, Alsó kikötő sor 9, Szeged 6726, Hungary

2 Plant Protection Institute, Centre for Agricultural Research, Herman Ottó u. 15, Budapest 1022, Hungary

3 Department of Field Crops Research, National Agricultural Research and Innovation Centre, Alsó kikötố sor 9, Szeged 6726, Hungary

4 Agricultural Institute, Centre for Agricultural Research, Brunszvik u. 2, Martonvásár 2462, Hungary to Europe as a weed of primary cereals such as wheat and barley. Oats are produced on nearly 6 million ha in Europe (http://www.fao.org/faostat). In Hungary, oat production has been continuously decreasing for years, with a growing area of 37.000 and 26.000 ha in 2017 and 2018, respectively (http://www.ksh.hu/docs/hun/xftp/gyor/vet/vet1806.pdf). However, oat is an excellent livestock feed rich in proteins, starch, fat, E and B vitamins, and it is also important for human nutrition and food processing.

Several plant diseases (e.g. rusts, leaf blotches, Fusarium head blight, smuts and a viral disease caused by barley yellow dwarf virus) have been threatening the production of oat throughout the world, of which Pyrenophora leaf blotch and crown rust are considered the two most important fungal diseases (Simons 1985; Murray et al. 2008; Dietz et al. 2019). Oat is susceptible to several Pyrenophora species, but Pyrenophora leaf blotch is only attributed to P. chaetomioides Speg. (syn: P. avenae Ito and Kurib. apud Ito; anamorph: Drechslera avenacea [Curtis ex Cooke] Shoem., syn: D. avenae [Eidam] Scharif) (Sivanesan 1987). Indeed, out of the members of the genus Pyrenophora this pathogen has been recorded on 
oat most frequently (Farr and Rossman 2019). Besides leaf blotch symptoms, $P$. chaetomioides can also cause leaf stripes or spots (Ellis 1971), elongated or irregular stem spots (Harder and Haber 1992), stem darkening at the nodes (black stem) leading to stem-break in severe cases (Luke et al. 1957), spikelet-drop (Ivanoff 1963), grain darkening (Blum 1997) and seedling blight, and occurs throughout most oat-growing areas (Ellis and Waller 1973a; CABI/EPPO 1991; Farr and Rossman 2019). In case of severe infection, the pathogen destroys much of the leaf tissue, resulting in lightweight, shrivelled and darkened grains of inadequate quality for further processing (Bocchese et al. 2006).

Although the species name $P$. chaetomioides refers to the sexual form of the pathogen, the role of pseudothecia and ascospores in the fungus' disease cycle as overwintering structures and primary inoculum is not so clear, because they are rarely mentioned in the literature (Martinelli 2004) or uncommon in the field (Ellis and Waller 1973a). However, pseudothecia of $P$. chaetomioides were often found on residues of oat crops in the south of Brazil (Martinelli et al. 2003). The asexual form of $P$. chaetomioides produces conidia, which are considered to be the main source of inoculum for the grains and for subsequent oat crops as the fungus is not a natural inhabitant of the soil (Shaner 1981) in the lack of resting spores (Reis 1987). Thus, primary infection may come from mycelium or conidia present on the seed, whereas the secondary infection is assured by air-borne conidia released from the infected tissues (Ellis and Waller 1973a).

In 2014, oval-like and short longitudinal necroses surrounded with chlorotic halo were observed sporadically on leaves of the winter oat variety GK Impala in an expermental site at Domaszék, Southeast Hungary. Other oat varieties in the adjacent plots were symptomless. Conidia on the necrotic spots resembled those of the fungal genus Drechslera (anamorph of Pyrenophora), which includes several cereal pathogenic species. In 2016, leaf symptoms and conidia similar to those observed on GK Impala were found on an unknown oat variety growing in the experimental field of Agricultural Institute, Centre for Agricultural Research (Martonvásár, Central Hungary). Since the genera Pyrenophora and Drechslera had not been reported from oat in Hungary, our aim was to isolate and identify the fungal species causing the observed leaf spots.

\section{Materials and methods}

\section{Sample collection and fungal isolation}

Leaf samples of GK Impala (Fig. 1) were collected at the end of February 2014, whereas leaves from Martonvásár were sampled in February 2016. In the laboratory leaves were placed into moist chambers (water-logged filter papers in glass Petri-dishes), which were incubated under white light (OSRAM model L36W/640) in a $16 \mathrm{~h}$ light/ $8 \mathrm{~h}$ dark cycle for $24 \mathrm{~h}$ at $20-22{ }^{\circ} \mathrm{C}$ in order to induce conidiogenesis. Two monoconidial isolates, one from each sampling site, were made aseptically in a laminar air flow device by transferring conidia from the leaves to potato dextrose agar plates (PDA, Oxoid, Becton, Dickinson and Company, Sparks, MD, USA; $19.5 \mathrm{~g}$ PDA, $7.5 \mathrm{~g}$ of agar and $1 \mathrm{~L}$ of distilled water) with a sterile needle, using a Leica MZ6 stereomicroscope at $40 \times$ magnification. Plates were incubated for 10 days in the dark at $20-22{ }^{\circ} \mathrm{C}$, then stock cultures were made on PDA slants and kept under mineral oil at $15^{\circ} \mathrm{C}$.

\section{Molecular identification}

Isolates were cultivated in potato dextrose broth at $22-25{ }^{\circ} \mathrm{C}$ for 10 days. Mycelium was harvested by vacuum-filtration, washed with sterile deionized water, freeze-dried and ground in liquid nitrogen. Pulverized mycelia were kept at $-70{ }^{\circ} \mathrm{C}$ till DNA extraction. Total genomic DNA was isolated with the NucleoSpin Plant II Genomic DNA Purification Kit (Macherey-Nagel GmbH \& Co. KG, Düren, Germany) according to the manufacturers' instructions. DNA regions spanning the internal transcribed spacer (ITS1-5.8S-ITS2) of the ribosomal RNA gene were amplified using primers ITS 1 and ITS4 (White et al. 1990). PCR reaction mixtures and conditions were as described previously (Nagy et al. 2003), except that annealing was at $57{ }^{\circ} \mathrm{C}$ for $30 \mathrm{~s}$. The amplification products were separated by electrophoresis in 1.7\% agarose gel, stained with ethidium bromide, and visualised under UV
Fig. 1 Symptomatic leaves of GK Impala collected in Domaszék. The arrow shows the lesion from which isolate $\mathrm{H}-503$ was derived

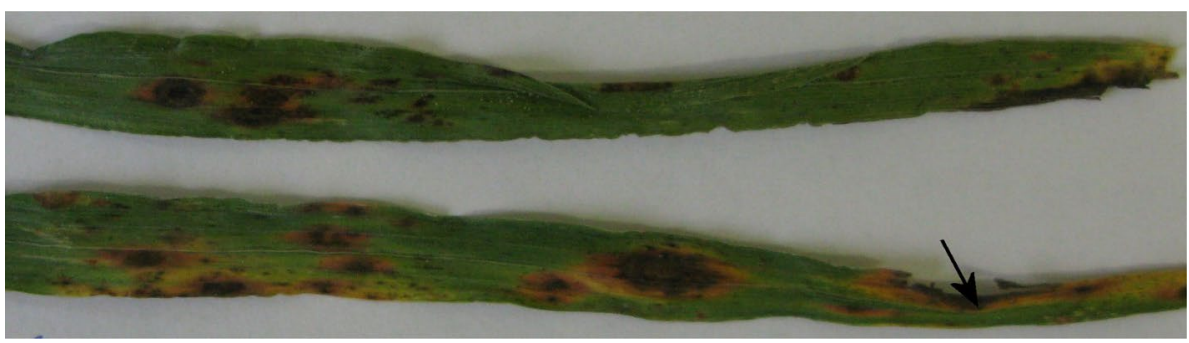


light. Clean-up of amplified products and Sanger sequencing were carried out in both directions with the PCR primers by Macrogen Europe (Amsterdam, The Netherlands). Forward and reverse sequence reads were combined into contigs, and identity of the derived consensus sequences were verified against data in GenBank (http://www.ncbi. nlm.nih.gov) using the Basic Local Alignment Search Tool (BLAST).

\section{Inoculum production and pathogenicity test}

To produce inocula for the artificial inoculation experiments, isolates were grown on V8-juice agar (V8; $16 \mathrm{~g}$ agar, $3 \mathrm{~g}$ $\mathrm{CaCO}_{3}, 100 \mathrm{ml}$ Campbell's V8 juice, $900 \mathrm{ml}$ distilled water) in $90 \mathrm{~mm}$ diameter plastic Petri's plates under white light (OSRAM model L36W/640) in a $16 \mathrm{~h} \mathrm{light/8} \mathrm{h}$ dark cycle at $20-22{ }^{\circ} \mathrm{C}$ for 10 days. Then sterile distilled water containing $0.01 \%$ Tween 20 was added to the sporulating cultures (10 ml solution per plate), and conidia were removed from the conidiophores by gently agitating the mycelium mat with a sterile paint brush. Finally, the conidium suspension was filtered through a fine sieve with $100 \mu \mathrm{m}$ diameter pore size and concentration of conidia was adjusted to $1 \times 10^{3} / \mathrm{ml}$.

Pathogenicity of isolates was tested in whole-plant or detached-leaf assays. In the whole-plant tests, $3 \times 4$ seedlings of both oat (GK Impala or Mv Pehely) and barley (GK Judy or Botond) were grown in pots in the greenhouse in natural light/dark cycle. GK Impala and GK Judy were sprayed at 2-leaf stage until runoff with the conidium suspensions of isolate H-503 collected from GK Impala in Domaszék. Mv Pehely and Botond were treated the same way with conidium suspension of isolate H-507 collected in Martonvásár. After spraying all plants were covered with a transparent plastic bag in the first $48 \mathrm{~h}$ to ensure $100 \%$ relative humidity during conidium germination and fungal penetration. In the detached-leaf assay, 7-8 cm long leaf segments of oat (GK Impala), barley (GK Judy) and wheat (GK Garaboly) seedlings were removed from the middle part of second leaves. The leaf pieces were fixed to the bottom of plastic Perti-dishes by placing narrow stripes of $1.5 \%$ tap water agar amended with $0.004 \%$ benzimidazol onto the ends of leaf segments, then a drop of conidium suspension of isolate H-503 was pipetted onto the central part of leaf segments $(3 \times 4$ segments/cultivar/isolate). In both the whole-plant and detached leaf-tests, controls were treated with sterile distilled water containing $0.01 \%$ Tween 20 . Inoculated and control plants/leaves were kept at $20 / 15^{\circ} \mathrm{C}$ (day/night) in natural light/dark cycle in the glasshouse. Evaluation of symptoms took place on the 10th day after inoculation in both types of the pathogenicity test. To fulfill Koch's postulates, symptomatic leaves were incubated in moist chamber, and conidia, if present, were isolated on PDA as described above.

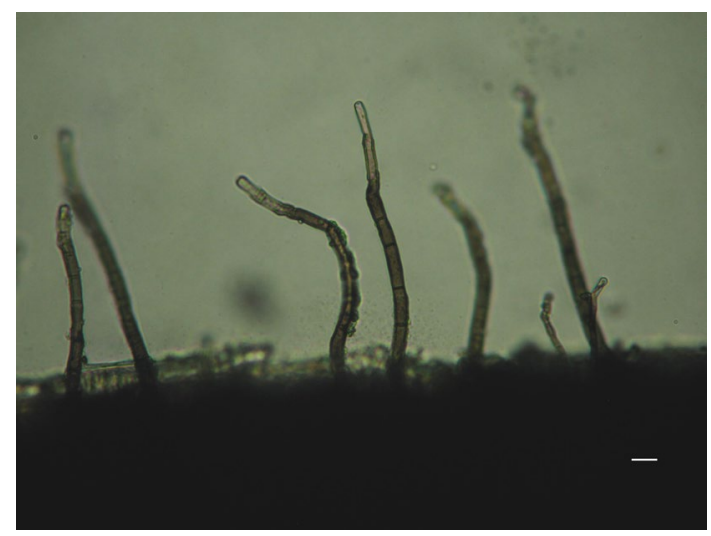

Fig. 2 Conidiophores formed on the necrotic leaf spot shown in Fig. 1. Bar $=10 \mu \mathrm{m}$

Fig. 3 A conidium collected from the necrotic leaf spot shown in Fig. 1. Bar $=10 \mu \mathrm{m}$

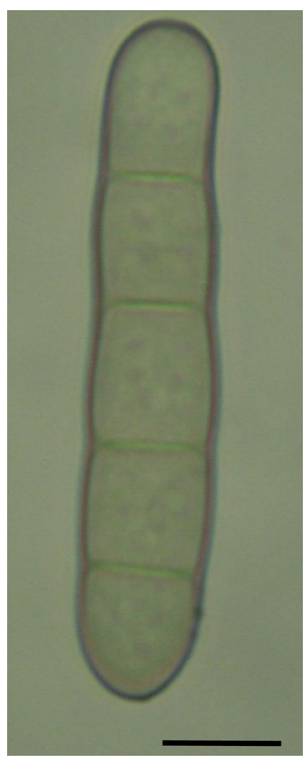

\section{Morphological characterisation}

Conidiophores and conidia scraped off the naturally infested leaf samples were visualised at the time of fungal isolations (Figs. 2, 3). Colony morphology was assessed by growing each monoconidial strain on $20 \mathrm{ml}$ PDA in 90-mm-diameter Petri-dishes in the dark at $25{ }^{\circ} \mathrm{C}$ for 10 days. Since Drechslera conidia on agar media are often atipical and rarely formed, the main conidial characteristics such as shape, size and number of pseudoseptae were recorded for 25 conidia collected from artificially inoculated oat leaves in the whole-plant pathogenicity tests. All microscopic work was done with an Olympus BX51 light microscope at $400 \times$ magnification. 


\section{Results}

\section{Molecular identification}

PCR amplification of ITS regions from isolates $\mathrm{H}-503$ and $\mathrm{H}-507$ resulted in DNA bands of the expected size (not shown). Direct sequencing of the amplified DNA fragments did not reveal any ambiguous nucleotide sites, and BLASTn search showed that the 547 nucleotide long ITS1-5.8S-ITS2 sequence of isolate H-503 (GenBank Accession no. KM396367) and isolate H-507 was completely identical to those of several $P$. chaetomioides reference isolates (e.g. AF260328, KJ415521, JN943661).

\section{Pathogenicity}

In the whole-plant tests, isolate H-503 from Domaszék initiated $0.5-1.5 \mathrm{~cm}$ long necrotic lesions with dark brown or greyish center and light brown or reddish outer zone on young leaves of the oat variety GK Impala. The lesions often coalesced and formed large, $2.5-5 \mathrm{~cm}$ long necroses in the entire width of leaf blades (Fig. 4a). In contrast, barley leaves (GK Judy) inoculated with this isolate exhibited restricted lesions, mainly along the edge of leaf blades (Fig. 4b). Symptoms caused by the other isolate (H-507) on oat (Mv Pehely) and barley (Botond) ranged from necrotic flecks to small spots of up to 4-5 $\mathrm{mm}$ in size, but the number of lesions and extent of chloroses were clearly greater on oat than on barley.(Figure $4 \mathrm{c}, \mathrm{d})$. In the detached-leaf assay H-503 caused large reddish-brown lesions spreading from the inoculation site towards the tip and the bottom of the oat leaf segments (GK Impala), barley (GK Judy) showed a few short and narrow scattered necrotic streaks, whereas wheat leaves (GK Garaboly) remained symptomless (Fig. 5). Control leaves never showed any sign of disease in either test (not shown). Sporulation of both isolates was abundant on oat leaves from which they were succesfully reisolated. In contrast, only a few conidia were observed on the inoculated barley leaves. In both cases, conidia were similar to those observed on the naturally infected oat leaves.

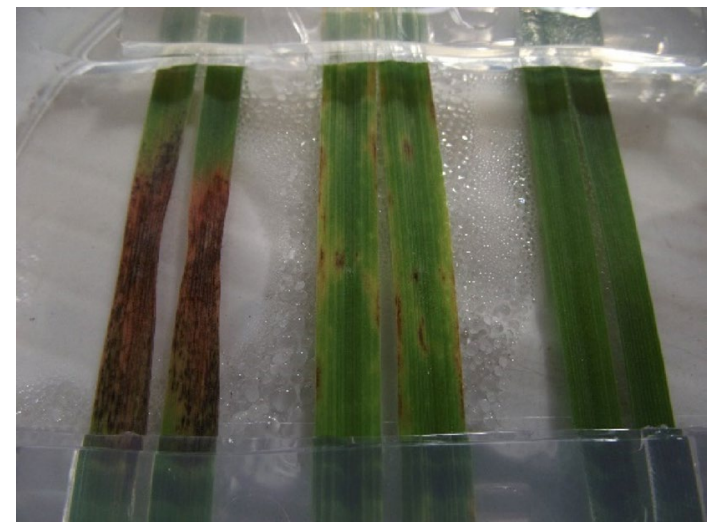

Fig. 5 Symptoms developed on oat (left), barley (middle) and wheat (right) leaf segments at 10 days after inoculation with isolate $\mathrm{H}-503$ in the detached-leaf pathogenicity test

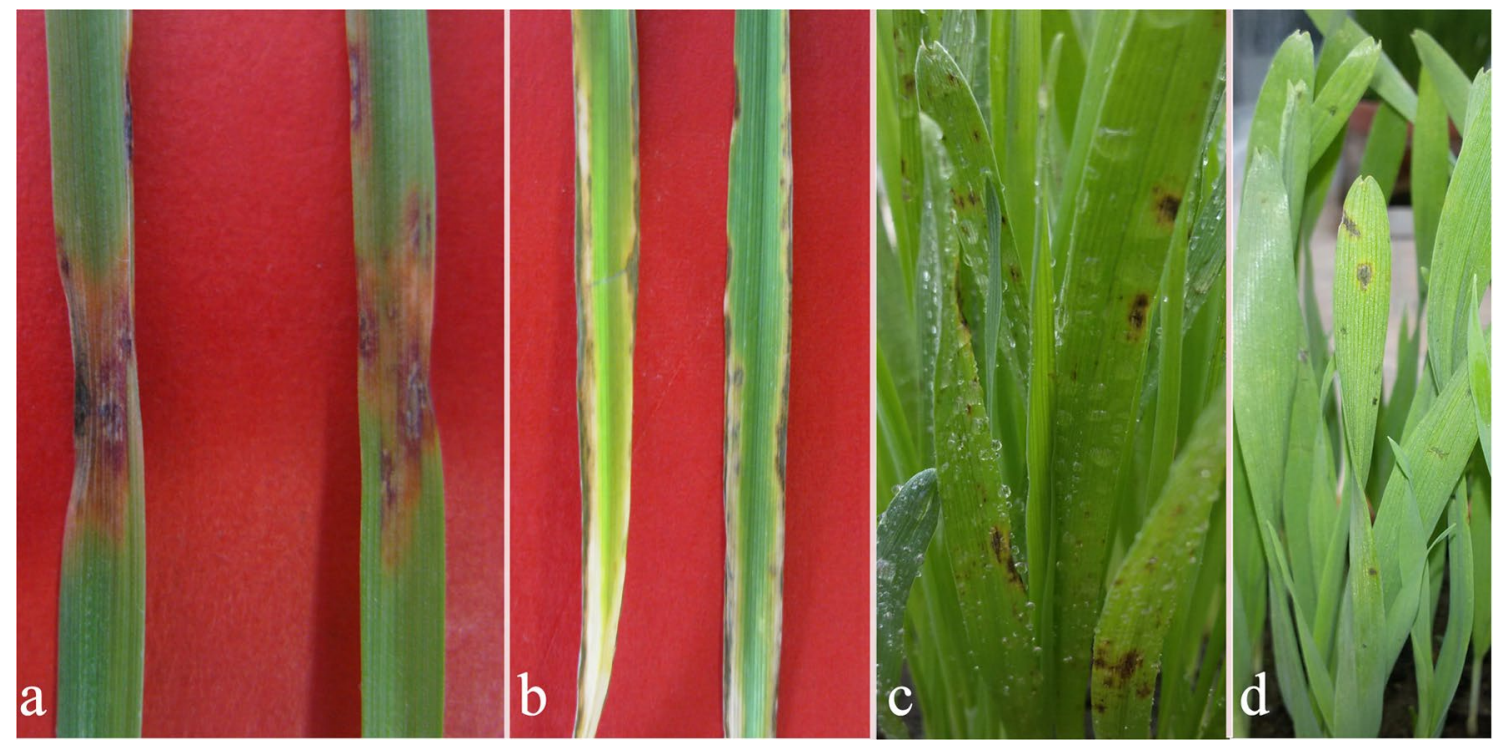

Fig. 4 Symptoms developed on oat (a and $\mathbf{c}$ ) and barley (b and $\mathbf{d}$ ) leaves at 10 days after inoculation with isolates $\mathrm{H}-503$ (a and b) or H-507 (c and $\mathbf{d}$ ) in the whole-plant pathogenicity tests 


\section{Morphology}

Conidiophores on both the naturally and artificially diseased leaf tissues were single or in small groups, dark brown, and bore hyaline to olive brown, smooth-walled, almost cylindrical conidia (Figs. 2, 3) with rounded ends and inconspicuous hylum. Conidia were mostly solitary or in short chains due to formation of secondary and tertiary conidia. Length and width of conidia on oat leaves inoculated with isolate H-503 were 53-68 (av. 60.5 \pm 5.6$) \times 10-14$ (av. 11.9 \pm 1.2 ) $\mu \mathrm{m}$, with basal cells $7-15.6$ (av. $12.8 \pm 2.8$ ) $\mu \mathrm{m}$ long and 10-11.6 (av. 10.6 \pm 0.4 ) $\mu \mathrm{m}$ wide and 3-5 pseudoseptae. Dimension of conidia of isolate H-507 was 81-121 (av. $100.3 \pm 10.8) \times 15.4-23.8$ (av. $19.1 \pm 2.2$ ) $\mu \mathrm{m}$, with basal cells 13.2-26.4 (av. 21.5 \pm 3.1 ) $\mu \mathrm{m}$ long and 12.7-26.4 (av. $17.6 \pm 3.2) \mu \mathrm{m}$ wide and 4-6 pseudoseptae. On PDA, cultures of both isolates were greyish, cottony, uniform, and did not form conidia or other structures (Fig. 6).

\section{Discussion}

The aim of this study was to identify two fungal isolates causing necrotic leaf spots on oat in two remote regions of Hungary, the Southern Great Plain and Central Transdanubia. Morphology of cultures and conidia matched well the description of genus Drechslera, the asexual stage of Pyrenophora, but accurate species identification could have not been achieved due to overlapping morphology and host range among the oat and the barley pathogenic Pyrenophora spp. (Shoemaker 1962; Sivanesan 1987; Ellis and Waller 1973a, b, c). Although the natural host and high pathogenicity of both isolates to oat strongly suggested that they

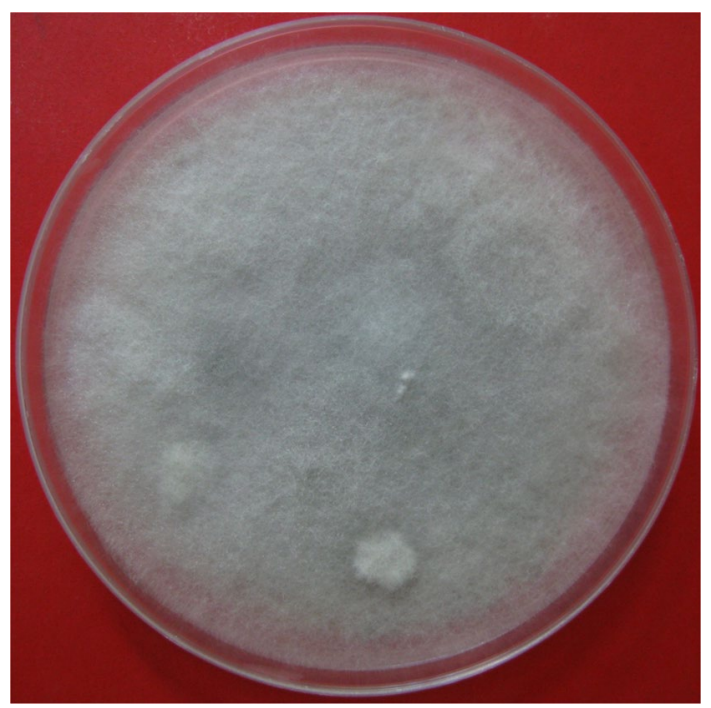

Fig. 6 A 10-day-old culture of isolate H-503 on PDA represented the primarily oat pathogen $P$. chaetomioides Molecular identification based on rDNA ITS sequences proved our hypothesis unambiguously since there was no mismatch among ITS sequences of our isolates from oat and a number of authentic $P$. chaetomioides reference strains.

We observed a considerable difference in the size of conidia between the two tested isolates. However, the majority of dimensional data we recorded were within the range reported for $P$. chaetomioides. For instance, Sivanesan (1987) published that the length and breadth of conidia of the axesual form of $P$. chaetomioides were 50-130 $\times 15-20 \mu \mathrm{m}$ with 1-9 distoseptae on the host, whereas Shoemaker (1962) recorded conidial dimensions of 34-131 $\times 10-22 \mu \mathrm{m}$ and 3-7 pseudoseptae on the host. The asexual spores we measured were collected from artificially infected leaves kept under greenhouse and laboratory conditions which might also put an effect on spore size, in addition to spontaneous intraspecific variation.

In the pathogenicity trials both tested isolates caused extending necrotic and chlorotic lesions on oat. Moreover, isolate H-503 from GK Impala were much more pathogenic to oat than to barley, and was non-pathogenic to wheat. Isolate H-507 also caused more damage on oat leaves. Successful reisolations from the inoculated oat leaves confirmed the isolates' pathogenicity to this host plant and fulfilled Koch's postulates. The weak pathogenicity of both isolates to barley is in agreement with the very rare field observations of P. chaetomioides on Hordeum. Barley has seldom been mentioned as an alternative host of $P$. chaetomioides. Ellett (1964) observed traces of leaf spots caused by $P$. chaetomioides in barley fields in Ohio, and Murvanishvili (1964) mentioned the association between $P$. chaetomioides and Hordeum leporinum in Georgia (USSR), but that time species identity could not be confirmed by molecular methods. According to Sivanesan (1987) the main host of P. chaetomioides is oat, occasionally other grasses such as Triticum. In our case, maybe specific interactions between isolate $\mathrm{H}-503$ and the tested wheat cultivar resulted in the incompatible relationship.

P. chaetomioides is a cosmopolitan fungus (Ellis and Waller 1973a; CABI/EPPO 1991) and infects mainly Avena spp., but it has also been reported from several other grasses (e.g. Festuca rubra, Lolium multifolrum, Paspalum platense, Triticum spp.) (Farr and Rossman 2019). In Europe, the imperfect stage of the pathogen was first found in the Pavia region of Italy in 1889 (Briosi and Cavara 1889), although the fungus usually has great impact in cool and moist climates of Europe and North America (Sivanesan 1987). In Finland, P. chaetomioides was observed in $60 \%$ of the oat fields in 1972-1973, and this high incidence had not changed by 2009 (Jalli et al. 2011). The fungus was also common in Sweeden (Oloffson 1976). In Central Texas 50-100 percent of the leaf tissue 
was destroyed in experimental stations in 1973, but commercial fields were also heavily impacted, presumably due to the weather conditions favourable for the disease, not to the occurrence of a new race/pathotype (Gough and McDaniel 1974).

To our knowledge, there is a sole study mentioning the occurrence of Pyrenophora leaf blotch in Hungary, and that was based on visual examination of symptoms. Šebesta et al. (2001) reported about the low incidence of disease in Martonvásár in 1998 as a result of a FAO project surveying European and Mediterranean nurseries from 1994 to 1998. Out of the countries which are close to Hungary, the authors recorded leaf symptoms with moderate or high incidence in Austria, with low to high incidence in Czech Republic, and with low or moderate frequency in the former Yugoslavia and Poland. Interestingly a previous survey from 1990 to 1993 did not mention the presence of Pyrenophora leaf blotch in Hungary (Šebesta et al. 1995). The fungus was also reported from Romania (Sivanesan 1987). Since Šebesta et al. (2001) applied visual examination, our study is the first to prove the presence of $P$. chaetomioides in Hungary based on isolation and accurate identification of the causal agent. In addition, we confirmed the observation of Šebesta et al. (2001) in that the disease exists in experimental plots in Hungary. However, there is still no information about its presence and economic importance in commercial fields, nor about the resistance of local oat varieties. Šebesta et al. $(1995,2001)$ has found large variation in the quantitative resistance of oat genotypes to the fungus' European populations, indicating pathogenic specialization and differences in aggressiveness of the causal agent. Quantitative resistance has also been found in other continents, for instance in North and South America (Frank and Christ 1988; Bocchese et al. 2001).

$P$. chaetomioides was reported to be important in cold and wet climates (Sivanesan 1987). Relatively low temperature $\left(20-24{ }^{\circ} \mathrm{C}\right)$ together with rain or high humidity facilitate leaf infections (Shaner 1981). These weather conditions may exist in Hungary in late spring and early summer in the last 2-3 months of oats' vegetation period, but obviously the pathogen has yet not caused considerable loss for the growers. Perhaps the relatively small growing area of oat, seed dressing and spraying of foliage with fungicides have ensured enough protection against the epidemic occurrence of the disease. In spite of this it would be desirable to survey $P$. chaetomioides in the fields and test the resistance of locally produced/bred oat varieties.

Acknowledgements Open access funding provided by MTA Centre for Agricultural Research (MTA ATK). Research work in ATK was supported by Grant NKFI 119276.
Open Access This article is licensed under a Creative Commons Attribution 4.0 International License, which permits use, sharing, adaptation, distribution and reproduction in any medium or format, as long as you give appropriate credit to the original author(s) and the source, provide a link to the Creative Commons licence, and indicate if changes were made. The images or other third party material in this article are included in the article's Creative Commons licence, unless indicated otherwise in a credit line to the material. If material is not included in the article's Creative Commons licence and your intended use is not permitted by statutory regulation or exceeds the permitted use, you will need to obtain permission directly from the copyright holder. To view a copy of this licence, visit http://creativecommons.org/licenses/by/4.0/.

\section{References}

Blum MMC (1997) Pyrenophora avenae: ocorrencia, inoculo, patogenicidade e sobrevivencia (Pyrenophora avenae: occurrence, inoculum, pathogenicity and survival). Dissertation, Universidade Federal do Rio Grande do Sul. Porto Alegre, p 111

Bocchese CAC, Martinelli JA, Matsumura ATS, Federizzi LC, Desch LF, Tellier M (2001) Especificidade de Pyrenophora avenae aos tecidos da semente de Avena sativa e sua atividade enzimática (Specificity of Pyrenophora avenae for kernel tissues of Avena sativa and its enzymatic activity). Fitopatol Bras 26:180-184

Bocchese CAC, Martinelli JA, Federizzi LC, Rosa CRE (2006) Processo de infecção e formação de manchaem grãos de aveia branca com níveis diferenciados de resistência para $P y r$ enophora chaetomioides (Infection process and spot development on kernels of white oats with differentiated levels of resistance against Pyrenophora chaetomioides). Fitopatol Bras $31: 284-290$

Briosi G, Cavara F (1889) I Fungi Parassiti della Piante Coltivate od utili essicati, delineati e descritti. Fasc. IV: no. 80

CABI/EPPO (1991) Pyrenophora chaetomioides. Distribution maps of plant diseases no. 105, 4th edn. CAB International, Wallingford

Dietz JI, Schierenbeck M, Simón MR (2019) Impact of foliar diseases and its interaction with nitrogen fertilization and fungicides mixtures on green leaf area dynamics and yield in oat genotypes with different resistance. Crop Prot 121:80-88

Ellett CW (1964) Wheat and oat diseases in Ohio in 1963. Plant Dis Rep 48:487-488

Ellis MB (1971) Dematiaceous hyphomycetes. Commonwealth Mycological Institute, Kew

Ellis MB, Waller JM (1973a) Pyrenophora avenae. CMI Descriptions of pathogenic fungi and bacteria no. 389. Commonwealth Mycological Institute, Kew, Surrey, England

Ellis MB, Waller JM (1973b) Pyrenophora graminea. CMI descriptions of pathogenic fungi and bacteria no. 388. Commonwealth Mycological Institute, Kew, Surrey, England

Ellis MB, Waller JM (1973c) Pyrenophora teres. CMI descriptions of pathogenic fungi and bacteria no. 390. Commonwealth Mycological Institute, Kew, Surrey, England

Farr DF, Rossman AY (2019) Fungal databases, U.S. National Fungus Collections, ARS, USDA. Retrieved on 7th Aug 2019 from https://nt.ars-grin.gov/fungaldatabases/

Frank JA, Christ BJ (1988) Rate-limiting resistance to Pyrenophora leaf blotch in spring oats. Phytopathology 78:957-960

Gough FJ, McDaniel ME (1974) Occurrence of oat leaf blotch in Texas in 1973. Plant Dis Rep 58:80-81

Harder DE, Haber S (1992) Oat diseases and pathologic techniques. In: Marshall HG, Sorrells ME (eds) Oat science and technology. American Society of Agronomy and Crop Science Society of America, Madison, pp 307-402 
Ivanoff SS (1963) The cause of spikelet drop of oat. Plant Dis Rep 3:206-207

Jalli M, Laitinen P, Latvala S (2011) The emergence of cereal fungal diseases and the incidence of leaf spot diseases in Finland. Agric Food Sci 20:62-73

Luke HH, Wallace AT, Chapman WH (1957) A new symptom incited by the oat leaf blotch pathogen, Helminthosporium avenae. Plant Dis Rep 2:109-110

Martinelli JA (2004) Oat diseases and their control. In: Reynolds SG, Suttie JM (eds) Fodder oats: a world overview. Plant Production and Protection Series no. 33. FAO, Rome, pp 197-214

Martinelli JA, Federizzi LC, Rosa CRE, Silva IF, Bocchese CAC (2003) Epidemiologia de espécies de Pyrenophora (Epidemiology of Pyrenophora species). In: Luz WC (ed) Revisão Anual de Patologia de Plantas, vol 11. RAPP, Passo Fundo, pp 255-281

Murray TD, Parry DW, Cattlin ND (2008) Diseases of small grain cereal crops: a colour handbook, 1st edn. CRC Press, Boca Raton, p 144

Murvanishvili IK (1964) New representatives of the mycoflora of Georgia. Soobshch Akad nauk Gruzinskoi SSR 33:643-650 (in Georgian language with Russian summary)

Nagy ZÁ, Bakonyi J, Érsek T (2003) Standard and Swedish variant types of the hybrid alder Phytophthora attacking alder in Hungary. Pest Manag Sci 59:484-492

Oloffson B (1976) Undersökning rörande Drechslera-arter has korn och havre (Survey of Drechlera species on barley and oat). Meddel Stat Vaxtskyd 16:323-425
Reis EM (1987) Sobrevivência de Fitopatógenos (Survival of plant pathogens). Econtro Paulista de Plantio Direto, Piracicaba, pp $73-89$

Šbesta J, Zwatz B, Corazza L (1995) Incidence of Pyrenophora avenae Ito et Kurib. in Europe and the varietal reaction of oat to it. Arch Phytopathol Plant Prot 29:485-490

Šebesta J, Zwatz B, Rodenick HW, Corazza L, Starzyk MH, Reitan L, Loskutov I (2001) Incidence of Pyrenophora avenae Ito et Kurib. in Europe between 1994-1998, and the varietal reaction of oats to it. Plant Prot Sci 37:91-95

Shaner G (1981) Effect of environment on fungal leaf blights of small grains. Annu Rev Phytopathol 19:273-296. https://doi. org/10.1146/annurev.py.19.090181.001421

Shoemaker RA (1962) Drechslera Ito. Can J Bot 40:809-836

Simons MD (1985) Crown rust. In: Roelfs AP, Bushnell WR (eds) The cereal rusts: diseases, distribution, epidemiology, and control. Academic Press, Orlando, pp 131-172

Sivanesan A (1987) Graminicolous species of Bipolaris, Culvurvularia, Drechslera, Exserohilum and their teleomorphs. Mycol Pap 158:1-261

White TJ, Bruns T, Lee S, Taylor J (1990) Amplification and direct sequencing of fungal ribosomal RNA genes for phylogenetics. In: Innes MA, Gelfand DH, Sninsky JJ (eds) PCR protocols: a guide to methods and applications. Academic Press, London, pp $315-322$ 